A look at the region

\title{
Five Years of Advanced Archaeometric Analysis at the Department of Analytical Chemistry, Faculty of Science, Palacký University in Olomouc
}

\author{
Lukáš Kučera $^{1 *}$, Petr Bednáŕ ${ }^{1}$ \\ ${ }^{I}$ Department of Analytical Chemistry, Faculty of Science, Palacký University in Olomouc, 17. listopadu 1192/12, 771 46, Olomouc, Czech Republic
}

\section{ARTICLE INFO}

Article history:

Received: $10^{\text {th }}$ January 2022

Accepted: $10^{\text {th }}$ February 2022

DOI: http://dx.doi.org/10.24916/iansa.2022.1.7

\section{Key words:}

archaeometry

analytical chemistry

organic residues

spectrometry

spectroscopy

chromatography

\begin{abstract}
$A B S T R A C T$
In modern archaeological research, a close multidisciplinary collaboration with other scientific areas is necessary, especially with natural sciences (e.g., anthropology, archaeobotany, and chemistry). This kind of collaboration and mutual evaluation of obtained results provides synergistically a series of important information in the context of prehistoric research nowadays. This systematic cooperation among archaeology, heritage science, anthropology, archaeobotany and analytical chemistry has been intensively developed for last five years at the Department of Analytical Chemistry, Faculty of Science, Palacký University in Olomouc. The aim of this short communication is to introduce our workplace and its activities with a focus on the most important outputs from various areas of the archaeometric research.
\end{abstract}

\section{Introduction}

Organic residues in archaeological findings are mostly characterised by archaeobotanical and archaeozoological expertise and common microscopic methods. For their chemical characterisation the focus is usually on the determination of several basic parameters, e.g., total organic carbon, total nitrogen, and the content of phosphate, sulphur, sodium, potassium, calcium, and magnesium. However, a more systematic chemical analysis of organic residues in an archaeological context using modern analytical techniques is often lacking (Goffer, 2005).

The residues of colorants and pigments on the surface of ancient material are studied using various procedures, as described in several articles (Leon, 2012; Pozzi, 2012; Parras, 2010). The most frequent techniques are based on mass spectrometry with various ionization techniques (i.e., MALDI, ICP-MS, and ESI) and microscopic techniques (i.e., PIXE, Raman microspectrometry, SEM, and EDX). Some of these methods are commonly used in archaeology, mainly for non-organic analysis, for example, mineral composition

*Corresponding author. E-mail: lukas.kucera@upol.cz of prehistoric ceramics (Santos Rodrigues, 2015) or metal artefacts (Oudbashi and Shekofteh, 2015). On the other hand, much less attention has been paid to an objective analysis of food residues in ancient findings, although these materials when studied comprehensively offer opportunities to obtain unique information. In many interesting cases, food residues have been found in localities connected with obsequies and other ancient mysteries. Chemical analysis can also help to prove some historical hypotheses, for example, the presence of garlic in graves as anti-vampire prevention and the use of various plant drugs (Cannabis sativa L., poppy extract, opium, etc.) in rituals (Askitopoulou, 2002). Perhaps the most inspirational approach well-worth following was called the Archaeological Biomarker Concept, as introduced by Evershed (2008).

In an effort to systematise analytical research in the field of analysis of organic and composite residues in archaeological finds, a project entitled "Advanced chemical analysis of residues of organic materials in archaeological context" was prepared by our team at the Department of Analytical Chemistry, Faculty of Science, Palacký University in Olomouc in cooperation with the Archaeological Centre, Olomouc, in 2016 and received funding the following year 

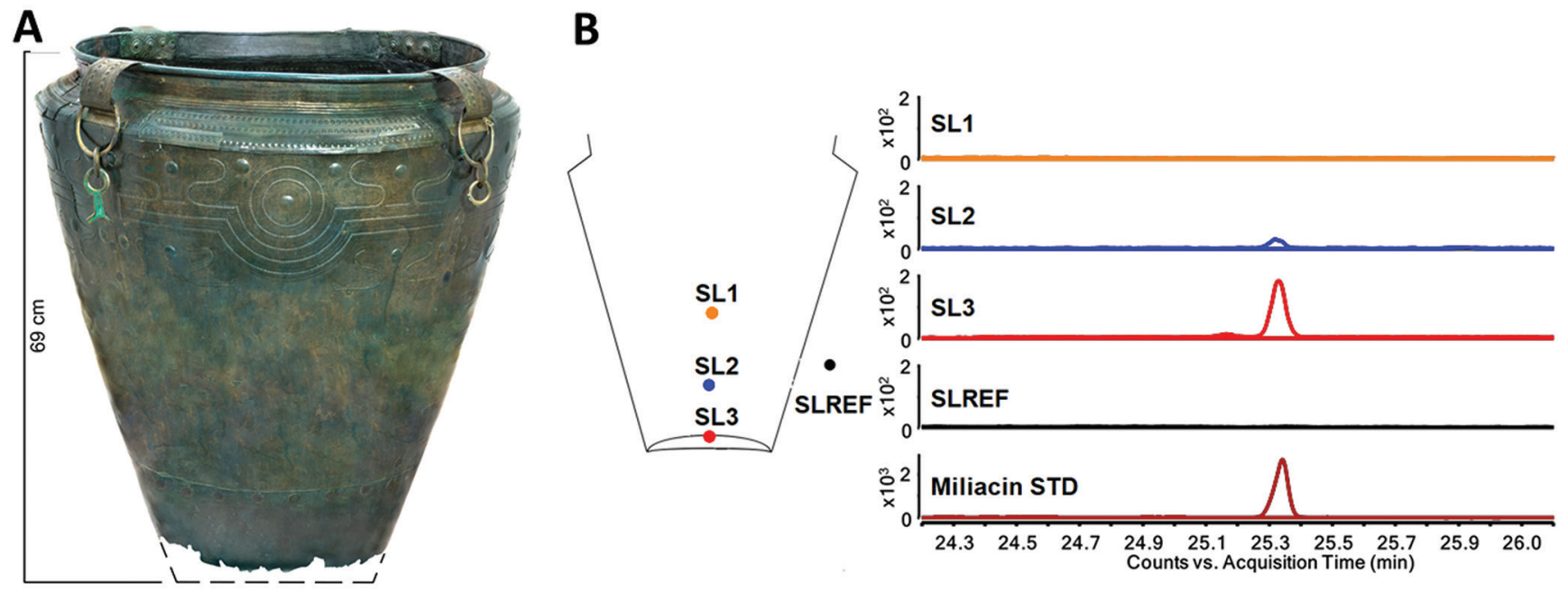

Figure 1. A: Photo of the bronze situla ("bucket”) of Kurd type, Kladina variant (photo Luděk Vojtěchovský); B: Chromatograms of MRM transition $440 \rightarrow$ 189 of soil extracts and miliacin standard.

from the Czech Science Foundation. This project helped to establish a wider group of cooperating experts from various areas and institutions: the Laboratory of Archaeobotany and Paleoecology (LAPE), Laboratory of Morphology and Forensic Anthropology (LaMorFA), Institute for Archaeological Heritage (UAPP), National Heritage Institute (NPU), Institute of Archaeology of the Czech Academy of Sciences in Prague (ARÚP AV ČR), the Czech Numismatic Society (mainly the Prague Groschen branch office) and other specialised workplaces. Cooperation has also been established at an international level, for example with the University of Wroclav (Poland), Eastern
Mediterranean University (N. Cyprus), National Museum in Belgrade (Serbia), Klaipeda University (Lithuania) and the Italian Institute for Conservation and Restoration under the Ministry of Culture (ISCR, Italy). Subsequently, a project in the Operational Programme of the European Union entitled: "Advanced physical-chemical methods of research and protection of cultural and artistic heritage" (OA ITI - ARTECA) was obtained and expanded the expertise of our laboratory to include historical art. The advanced analytical research is performed using modern scientific instrumentation, including six mass spectrometers with various mass analysers (quadrupole, triple quadrupole,

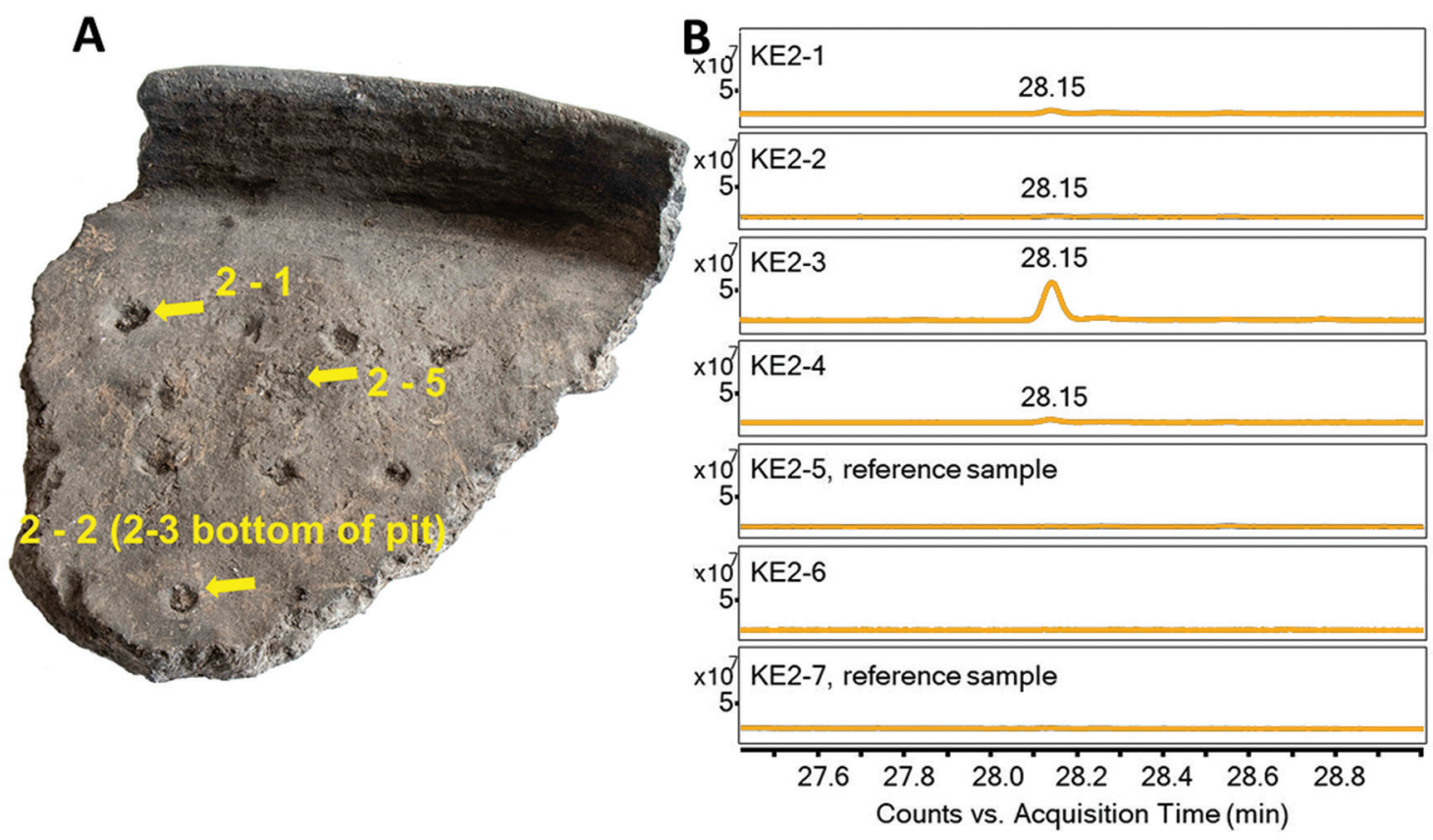

Figure 2. A: Part of the ceramic pan KE2; B: GC/MS analysis of acetone:chloroforme extract of samples - detection of cholesterol (samples of organic residue from the pit, KE2-1 and KE2-3; samples KE2-2 and KE2-4 were taken under KE2-1 and KE2-3, respectively; reference sample from the bottom of the pan, KE2-5; inner surface KE2-6 and reference sample from the surface, KE2-7). 
ion-trap, and hybrid quadrupole-time of flight) and various ion sources (electron impact and chemical ionisation, electrospray, chemical ionisation and photoionisation at atmospheric pressure, atmospheric solids analysis probe, desorption electrospray, and vacuum laser desorptionionisation (MALDI source)). These mass spectrometers are routinely hyphenated with separation techniques, i.e., GC, UHPLC and 2D-UHPLC as well. Two mass spectrometers (Synapt G2-S and Cyclic IMS) are equipped with an ion mobility cell allowing the separation of ions in accordance with their collision cross sections. Note that cyclic ion mobility is a unique and extremely efficient approach to separate compounds based on their collision cross sections, including very closed structures and true isomers (the recent installation of a Cyclic IMS system in the applicants' laboratory was only the third one in the world). The obtained results are continuously published in prestigious scientific journals. In the following text, the most important results recently obtained by our team are briefly reviewed.

\section{Case studies}

\subsection{Organic residues of food and beverages}

The soil content of two ceramic vessels belonging to the Moravian regional group of the Corded Ware Culture was analysed using the MALDI-MS technique. Several markers found in the soil layers taken from the bottom of the studied vessels correspond with signals of triacylglycerols typical for milk and/or dairy products. These results represent the first direct evidence of the utilisation of milk products in the Eneolithic period in the Moravian Corded Ware Culture. Moreover, triterpenoid miliacin that is a marker of millet was detected in this soil material by atmospheric solids analysis probe mass spectrometry (ASAP-MS) and gas chromatography/mass spectrometry (GC/MS). It should be emphasised that this was the first time the ASAP-MS technique was used in archaeological research worldwide. The presence of millet in an Eneolithic context is very important and extraordinary. It can be considered as the first such direct evidence of millet usage in Central Europe. Our data relating to the utilisation of milk and millet in the Early Neolithic-Eneolithic period in Eastern Central Europe (the Central Danube Region) significantly extend the former evidence of dairy products and millet usage in Western Central Europe (Germany, Switzerland) (Kučera et al., 2018; Kučera et al., 2019). The miliacin was also detected on the surface of a bronze situla from the Kladina site in East Bohemia (Pardubice district). The detection of miliacin (as a "chemical imprint" of millet; Figure 1) by chemical analysis opens the way for a better understanding of the composition of food remains, even in much older samples than those studied up to now, or procedures that would lead to complete corn decomposition (e.g., cooking, baking, fermentation, etc.). Archaeobotanical analysis (pollen and starch grains) pointed to the use of bitter herbs in a fermentation process. It can be concluded that this bronze situla contained the oldest (yet) millet-herbal beer in Europe (Jílek et al., 2021). The presence of millet in studied archaeological material has also been described in the following publications (Kučera et al., 2020; Golec et al., 2022). As can be seen, the combination of archaeobotanical and chemical analyses of archaeological samples is a powerful tool for revealing new information from human history. The next example is the analysis of Neolithic ceramic fragments of large, flat, elongated pans from North Macedonia (Figure 2). The attached material on the surface of the studied pan fragments was sampled for consequent chemical and microscopical analyses (i.e., analyses of starch, phytoliths, and microscopic animal remains). The main compound that occurred in all samples was cholesterol (found using GC/MS). A major source of cholesterol is animal fat and meat (its presence being proved by an immunological test). Based on these results, we suppose that the analysed ceramic pans from Ustie na Drim were used for the preparation of meals containing meat from common livestock in combination with cereals and wild plants (Beneš et al., 2021).

\subsection{Metal analyses}

Another area of current research is dealing with the analysis of metallic objects and the presence of organic residues on their surface (coins, ritual objects, decorations, jewels, etc.). The composition of a metal surface can influence the organic residues that adhere to its surface (for example, catalytic action, formation of organometallic adducts, etc) and, on the other hand, organic material can cause changes in the metal surface itself (for example, corrosion protection, either intended or accidental). A detailed analysis of coins from the Ladná hoard (a finding of more than 1000 coins; broad pfennigs and Moravian denarii discovered in the 1990s) was performed. Several methods were applied for assessing the original and actual fineness of the broad silver pfennigs from this hoard (Kučera et al., 2017). The knowledge from the above studies dealing with coin characterisation was applied in a study of the defects found on historical gold coins known as "gold corrosion" (Figure 3). Defects analysed in this study show a high content of iron and oxygen. The results show that silver and the consequent formation of $\operatorname{Ag}_{2} \mathrm{~S}$ is not the only possibility for the formation of red stains. The coins that are minted in thousands/millions of pieces have a higher risk of damaging the parts of devices used in the mint and thus contaminating a golden alloy with iron particles. This study expands our knowledge of the formation of "corrosion" products on gold coin surfaces and can be the primary impulse to control steel components during the minting process (Kučera et al., 2021). Another study dealt with the purpose of use of a bronze ornithomorphic plastic artwork, coming from an extensive hoard from the territory of the Liptov Basin (Central Slovakia), belonging, in terms of art, to some of the crucial artefacts of the European Bronze Age. GC/MS revealed the presence of particular fatty acids (isomyristic, oleic, stearic), monoacylglycerols (monomyristin, monopalmitin, monostearin) and cholesterol. Raman microscopy proved the presence of soot (based on signals at 1323 and $1589 \mathrm{~cm}$ ). 
X-ray fluorescence spectrometry confirmed that the material of the artwork is bronze. It can be concluded on the obtained data and formerly published studies that this object was used as a ceremonial lamp (Ondrkál et al., 2020). These studies particularly highlight the importance of the careful, but critical, interconnection of data that have been obtained from various analytical techniques and with archaeological expertise.

Recently, three copper alloy moulds from Moravia belonging to the Roman era were analysed by several analytical techniques, including XRF, GC/MS and a combination of atmospheric solid analysis probe-mass spectrometry with ion mobility spectrometry. The elemental composition (i.e., the higher content of $\mathrm{Pb}$ and $\mathrm{Zn}$ ) of two moulds pointed to the possibility of the production of "barbarian" alloys from remelted Roman objects. The internal part of all moulds contained carbon in the form of soot (identified by Raman microscopy). Moreover, the moulds contained solid material that was identified as a residue of ozokerite (earth wax, a naturally-occuring odoriferous mineral wax). We hypothesise that the remains of earth wax in these moulds point to their use for the production of wax models and the consequent use of these models for lost-wax ceramic casting (Jagošová et al., 2021).

\subsection{Exploration of works of art}

The XRF, a common and fast technique for metal analysis, can be advantageously used for the non-invasive exploration of works of art, for example, pigments and plasters. This kind of application was performed by our team in the case of a painting in The Tombs of the Via Ostiense in Rome (Figure 4; Marcelli et al., 2020).

An investigation of a scapular amulet from the collection of the Regional Museum in Olomouc was also conducted by a combination of various methods. GC/MS of four microsamples taken revealed the presence of dehydroabietic acid. The LDI-MS technique proved the presence of fatty acids as well as di- and triacylglycerols. Common organic dyes or pigments were not detected. The dark colour of the material is thus more related to inorganic black pigments (e.g., soot) than anything else. The high content of lead was found by
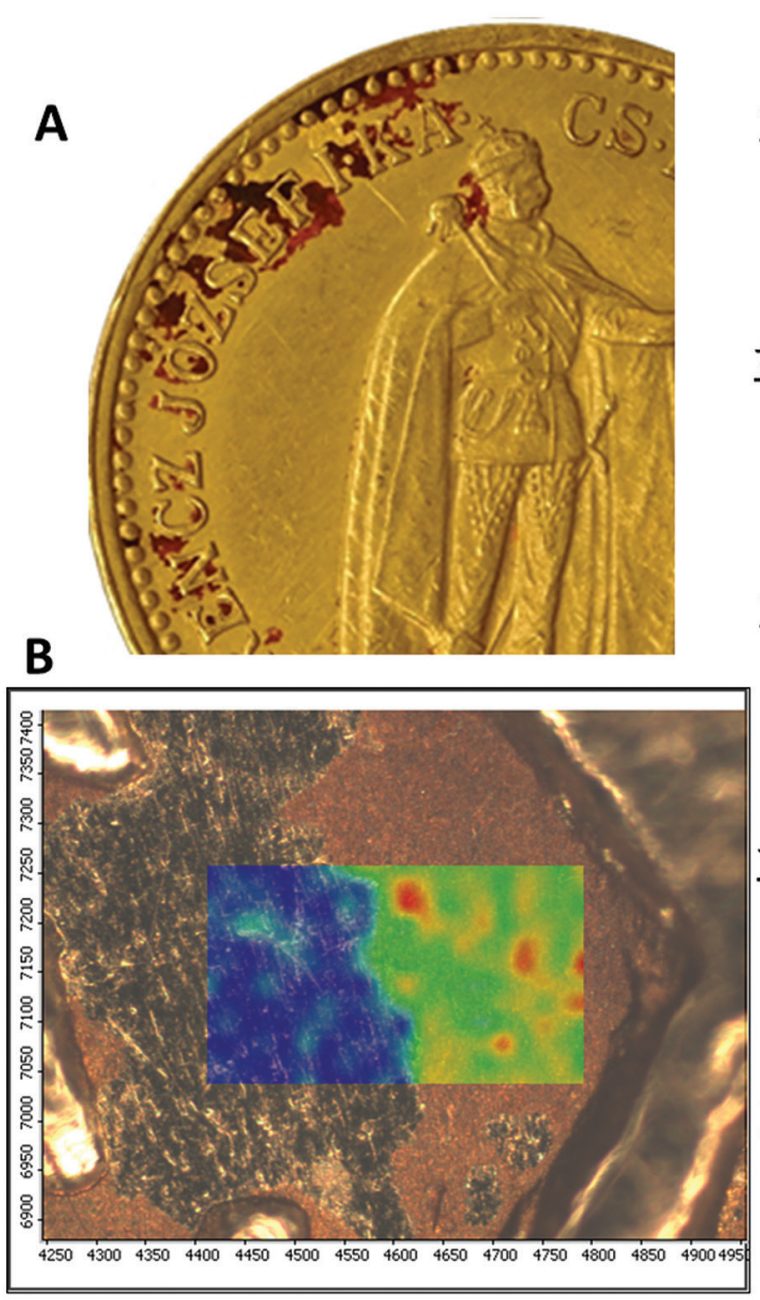

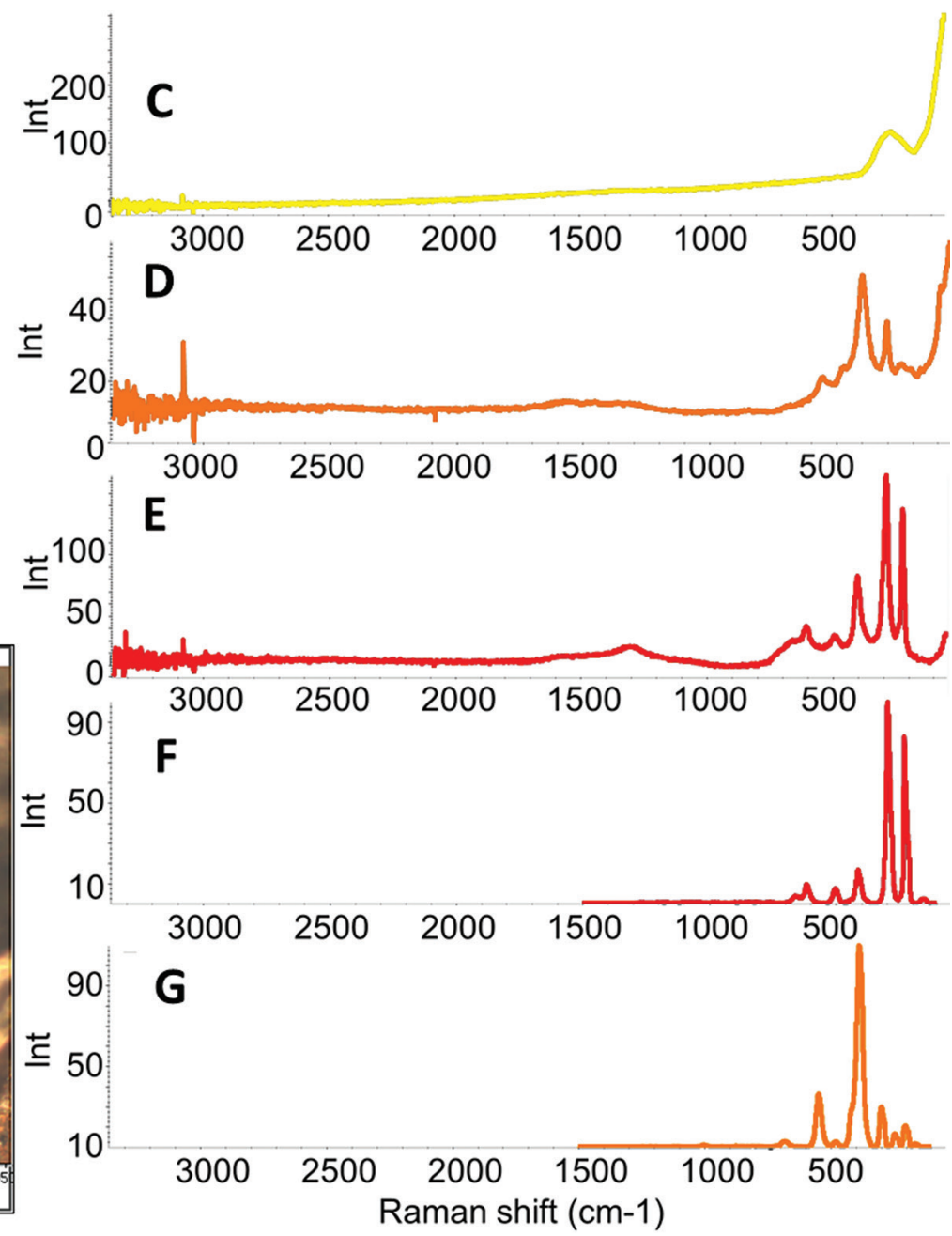

Figure 3. A: Austro-Hungarian 10 Korona 1905 affected by corrosion; B: Raman imaging of corrosion products on surface of Austro-Hungarian 10 Korona at the signal $394 \mathrm{~cm}^{-1}$ (the lowest intensity of Raman signal is shown by the blue colour and the highest intensity by the red colour); C: Raman spectra of 10 Korona and reference materials - area of pure gold; D: Analysis of red stain with laser energy $10 \mathrm{~mW}$; E: Analysis of red stain with laser energy $20 \mathrm{~mW}$; F: Spectrum of hematite standard; G: Spectrum of goethite standard. 

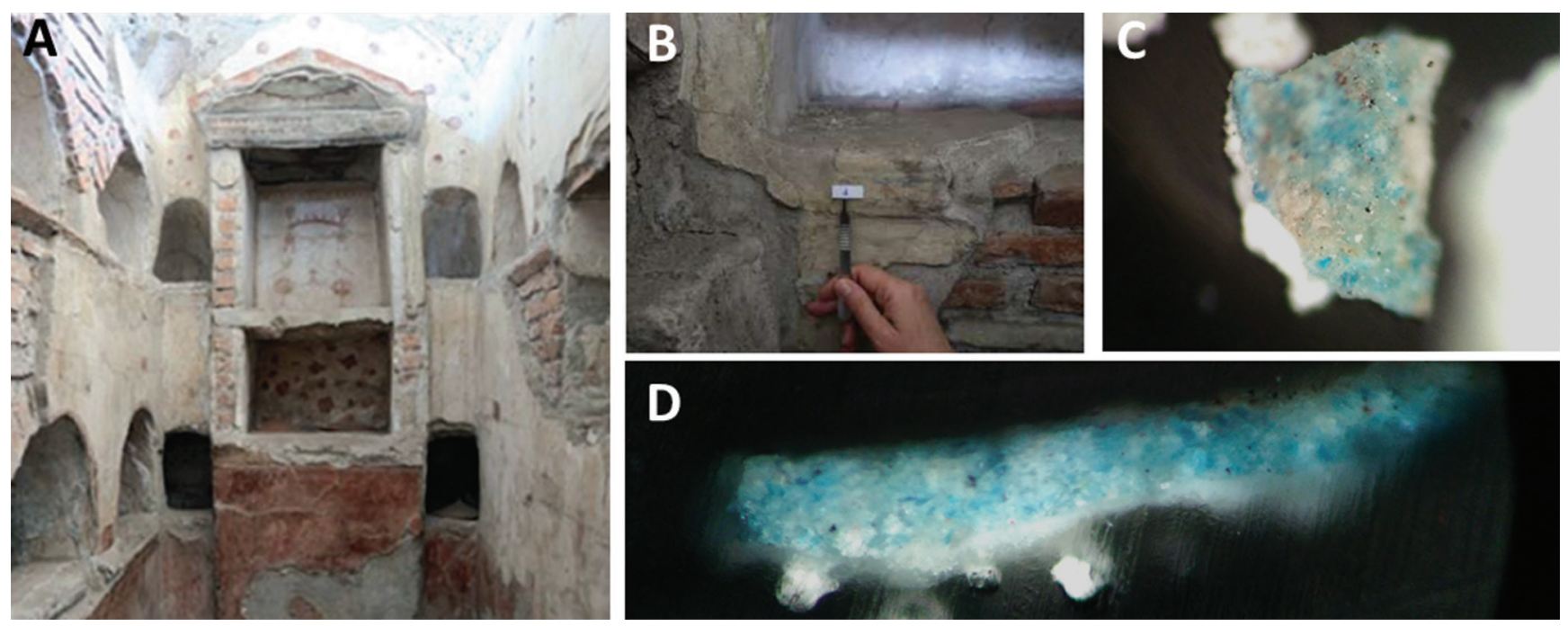

Figure 4. A: Tomb VII at the Via Ostiense in Rome; B: Place of sampling and XRF measurement; C: Detail of sample for consecutive preparation of crosssection; D: Stratigraphy of studied sample - the blue layer contained $33 \%$ copper, i.e., blue copper pigment.

ICP-MS, which was ascribed to the presence of siccative. With the support of these results, the studied material was described as an oil paint containing desiccant (Janusová et al., 2017).

\subsection{Analyses of resins and related compounds}

The combination of untargeted LDI-MS with MVA was applied to the classification of some amber findings. The composition of amber varies according to its origin. However, differences in its composition are reflected by relatively small changes in a huge number of signals that are nearly impossible to evaluate by (manual) spectral comparison and the classification of the ambers according to place of origin (geographical distribution) - and thus this task is predestined for MVA analysis. Amber samples from various archaeological sites of Western Lithuania and its coast were studied. The total segregation of raw amber samples from a strip-mine (Palmnicken in former East Prussia in the Sambian Peninsula, currently Kaliningrad Oblast, Russian Federation) and the seacoast (Lithuania) was observed in a Score Plot from a PCA analysis. The distribution of samples with respect to different localities was observed mainly in the direction of the first component axis (explaining 59.2\% of data variation; the first two principal component together explaining $82.2 \%$ of the variation) (Bliujiene and Kučera, 2018). This technique was used for the characterisation of amber findings from the basal layers at the Pod Hradem Cave (Moravian Karst) (Nejman et al., 2018) and amber samples from Mikulovice (Kučera and Bednár, 2020). The majority of amber is found in graves. In addition, other hardened resins (or some other natural compound) could be found. One example from the grave of an older woman attributed to the Iron Age Horákov Culture was the residue of hardened birch bark tar (identified by GC/MS), possibly a form of natural medicine (Holubová et al., 2020).

\subsection{Analyses of anthropological samples}

An interesting task was to analyse human teeth from some archaeological excavation to find a link between phosphate intensity changes in the human enamel and the light microscopy record of accentuated stress lines (ALs). This principle of dental "time-lapse records" is increasingly used for analytical purposes in palaeoanthropology and bioarcheology to reconstruct individual life histories from archaeological human skeletal remains. This human "barcode" pattern is unique to each person, preserving a record of individual life experience. Based on the obtained results, we suppose that Raman microscopy of ALs could offer a new and alternative perspective on enamel structures. In most cases, we found that the optical change in the light microscope corresponds to the change in phosphate concentration in the Raman microscope. However, Raman microscopy may not detect everything that is recognised by light microscopy. Raman microscopy can help us to decide which changes in the stress lines are related to changes in phosphate content and which are not (Vacková et al., 2021).

\section{Conclusion}

Our five years of experience in the field have shown conclusively that the very close cooperation of an analytical chemist with an archaeologist/art expert represents the principal premise for a reliable and coherent research of historical samples - from the disclosure of an archaeological locality and sample collection through to the analysis and data interpretation.

This close cooperation of analytical chemistry with archaeological area is reflected in our recent book (Bednár and Kučera, 2021). The book is devoted to the utilisation 
of modern techniques and methods of chemical analysis in the research of human history. It is intended for historians to provide them with detailed information on the possibilities, as well as the pitfalls, of current analytical procedures and for analytic chemists interested in research in the field of history, archaeology and cultural heritage. The book is freely available at www.vydavatelstviupol.cz as an iPDF.

\section{References}

ASKITOPOULOU, H., RAMOUTSAKI, I.A., KONSOLAKI, E., 2002. Archaeological evidence on the use of opium in the Minoan world. International Congress Series, 1242(0), 23-29.

BEDNÁŘ, P., KUČERA, L., 2021. Moderni chemická analýza varcheologii I. díl. Olomouc: Univerzita Palackého v Olomouci.

BENEŠ, J., TODOROSKA, V., BUDILOVÁ, K., KOVÁRNÍK, J., PAVELKA, J., ATANASOSKA, N., BUMERL, J., FLORENZANO, A., MAJEROVIČOVÁ, T., VONDROVSKÝ, V., PTÁKOVÁ, M., BEDNÁŘ, P., RICHTERA, L., KUČERA, L. , 2021. What about Dinner? Chemical and Microresidue Analysis Reveals the Function of Late Neolithic Ceramic Pans, Molecules, 26, 3391.

BLIUJIENE, A., KUČERA, L., 2018. Some remarks on amber usage tradition and amber provenance in the interfluve of Nemunas and Daugava rivers in the Migration Period. In: B. Niezabitowska-Wisniewska, et al., eds. Studia Barbarica. Lublin: UMCS.

EVERSHED, R.P., 2008. Organic residue analysis in archaeology: The Archaeological biomarker revolution. Archaeometry, 50, 895-924.

GOFFER, Z., 2005. Archaeological Chemistry. 2nd ed., New Jersey: John Wiley \& Sons, Inc.

GOLEC, M., GOLEC MÍROVÁ, Z., FOJTÍK, P., KUČERA, L., ŠMÍD, M., 2022. Banquet of elites: Hallstatt Period hoard with vessels and iron cauldron hanger of Kralice na Hané in Moravia (CZ). Journal of Archaeological Science: Reports, 41, 103319.

HOLUBOVÁ, Z., PŘICHYSTAL, M., DOBISÍKOVÁ, M., DRESLEROVÁ, G., KALA, J., KUČERA, L., PŘICHYSTAL, A., 2020. Halštatské pohřebiště v Brně - Hornich Heršpicich, Jantarová stezka $v$ proměnách času. Brno: Moravské zemské muzeum.

JAGOŠOVÁ, K., JÍLEK, J., FOJTÍK, P., ČIŽMÁŘ, I., POPELKA, M., KURKA, O., KUČERA, L., 2021. First Evidence of "Earth Wax" Inside the Casting Molds from the Roman Era. Molecules, 26(14), 4259

JANUSOVÁ, L., KUČERA, L., SMÉKALOVÁ, V., ZIKMUND, T., KAISER, J., 2017. Průzkum škapuliřového amuletu a jeho analogií ze sbírky Vlastivědného muzea v Olomouci. Fórum pro konzervátoryrestaurátory, 2017, 70-78.

JíLEK, J., GOLEC, M., BEDNÁR̆, P., CHYTRÁČEK, M., VÍCH, D., ZAVORAL, T., MÍROVÁ, Z., PETR, L., KOVÁRNÍK, J., MILO, P., KUČERA, L., 2021. The oldest millet herbal beer in the Europe? The ninth century BCE bronze luxury bucket from Kladina, Czech Republic. Archaeometry, 1-14.

KUČERA L., PEŠKA, J., FOJTÍK, P., BARTÁK, P., SOKOLOVSKÁ, D., PAVELKA, J., KOMÁRKOVÁ, V., BENEŠ, J., POLCEROVÁ, L., KRÁLíK, M., BEDNÁŘ, P., 2018. Determination of Milk Products in Ceramic Vessels of Corded Ware Culture from a Late Eneolithic Burial. Molecules, 23, 3247.

KUČERA L., BEDNÁŘ, P., 2020. Chemická analýza vzorků jantaru. In. M. Enreé, M. Langová, eds. Mikulovice - Pohřebiště starší doby bronzové na Jantarové stezce. Praha: Archeologický ústav AV ČR, Praha, pp. 414 417.
KUČERA, L., RICHTERA, L., ZMRZLÝ, M., JAROŠOVÁ, M., KUČEROVÁ, P., BEDNÁŘ, P., 2017. Problematika stanovení ryzosti středověkých mincí a porovnání běžně používaných technik. Folia Numismatica, 31(2), 3 .

KUČERA, L., BEDNÁŘ, P., GOLEC, M., FOJTÍK, P., 2020. Chemické analýzy prosa a tuku doby halštatské na Moravě. In: M. Golec, P. Fojtík, eds. Centrum platěnické skupiny východohalštatské kultury na Moravè. Archaeologica Olomucensia, 5, Olomouc: Univerzita Palackého v Olomouci, pp. 178-183.

KUČERA, L., PEŠKA, J., FOJTÍK, P., BARTÁK, P., KUČEROVÁ, P., PAVELKA, J., KOMÁRKOVÁ, V., BENEŠ, J., POLCEROVÁ, L., KRÁLÍK, M., BEDNÁR̆, P., 2019. First direct evidence of broomcorn millet (Panicum miliaceum) in Central Europe. Archaeological and Anthropological Sciences, 11(4), 4221

KUČERA, L., ROZSYPAL, J., BEDNÁŘ, P., BŘEZINA, M., KALINA, L., BEZDIČKA, P., MAŠLÁŇ, M., RICHTERA, L., 2021. "Gold corrosion" an alternative source of red stains on gold coins. Materialia, 2021, 101025.

LEON, Y., SCIAU, P., BOUQUILLON, A., PICHON, L., DE PERSEVAL, P., 2012. PIXE (particle induced X-ray emission): A non-destructive analysis method adapted to the thin decorative coatings of antique ceramics. Nuclear Instruments and Methods in Physics Research, Section B, Beam Interactions with Materials and Atoms, 291(0), 45-52.

MARCELLI M., PANNUZI, S., GIOVANNONE, C., MARINELLI, A.M., MICHALČÁKOVÁ, J., KUČERA, L., 2020. Metodologie d'indagine e problematiche conservative: gli affreschi del Sepolcreto della via Ostiense a Roma. In: V. Caminneci, M.C. Parello, M.S. Rizzo, eds. Animum pictura pascit (Verg., Aen. I, 464) Abitare con le pitture nel Mediterraneo antico. Bologna: Ante Quem, pp. 79-90.

NEJMAN, L., KUČERA, L., ŠKRDLA, P., LISÁ, L., HLADILOVÁ, Š., KRÁLÍK, M., WOOD, R., NÝVLTOVÁ-FIŠÁKOVÁ, M., WRIGHT, D., SULLIVAN, M.E., HUGHES, P., 2018. 2016 excavation of basal layers at Pod Hradem Cave and the finding of shell and amber. Př výzkumu , 59(1), 9-15.

ONDRKÁL, F., PEŠKA, J., JAGOŠOVÁ, K., SOKOLOVSKÁ, D., KUČERA, L., 2020. The Cult-Wagon of Liptovský Hrádok: First evidence of using the Urnfield cult-wagons as fat-powered lamps. Journal of Archaeological Science: Reports, 34, 102579.

OUDBASHI, O., SHEKOFTEH, A., 2015. Chemical and microstructural analysis of some Achaemenian silver alloy artefacts from Hamedan, western Iran. Periodico Di Mineralogia, 84(3A), 419-434.

PARRAS, D., VANDENABEELE, P., SANCHÉZ, A., MONTEJO, M. MOENS, L., RAMOS, N., 2010. Micro-Raman spectroscopy of decorated pottery from the Iberian archaeological site of Puente Tablas (Jaén, Spain, 7th-4th century B.C.). Journal of Raman Spectroscopy, 41(1), 68-73.

PIPERNO, D.R., FLANNERY, K.V., 2001. The earliest archaeological maize (Zea mays L.) from highland Mexico: New accelerator mass spectrometry dates and their implications. Proceedings of the National Academy of Sciences of the United States of America, 98(4), 2101-2103.

POZZI, F., POLDI, G., BRUNI, S., DE LUCA, E., GUGLIELMI, V., 2012. Multi-technique characterization of dyes in ancient Kaitag textiles from Caucasus. Archaeological and Anthropological Sciences, 4(3), 185-197. SANTOS RODRIGUES, S.F., DE COSTA, M.L., PÖLLMANN, H., KERN, D.C., DE SILVEIRA, M.I., KIPNIS, R., 2015. Prehistoric production of ceramics in the Amazon: Provenience, raw materials, and firing temperatures. Applied Clay Science, 107, 145-155.

VACKOVÁ, S., KRÁLíK, M., MAREČKOVÁ, K., RÁČKOVÁ, L., QUADE, L., SEDLÁČKOVÁ, L., FOJTÍK, P., KUČERA, L., 2021. Human "barcode": Link between phosphate intensity changes in human enamel and light microscopy record of accentuated lines. Microchemical Journal, 168, 106370 . 